\title{
Differential cytokine regulation by NF-KB and AP-1 in Jurkat T-cells
}

Hazem Khalaf1, Jana Jass\$1,2 and Per-Erik Olsson*1

\begin{abstract}
Background: Activator protein (AP)-1 and nuclear factor (NF)-KB largely control T-cell activation, following binding of foreign antigens to the T-cell receptor leading to cytokine secretion. Elevated levels of pro-inflammatory cytokines and chemokines such as TNF, IL-6 and CXCL8 are associated with several human diseases including cystic fibrosis, pulmonary fibrosis and AIDS. The aim of this study was to investigate the role of the transcription factors, AP- 1 and NF$\mathrm{KB}$, in IL-6 and CXCL8 regulation in Jurkat T-cells.
\end{abstract}

Results: Phorbol myristate acetate (PMA) exposure resulted in an up-regulation of AP-1 and down-regulation of NF-KB activity, however, exposure to heat killed (HK) Escherichia. coli MG1655 resulted in a dose-dependent increase in NF-KB activity without affecting AP-1. The cytokine profile revealed an up-regulation of the chemokine CXCL8 and the proinflammatory cytokines TNF, IL-2 and IL-6 following treatment with both PMA and HK E. coli, while the levels of the antiinflammatory cytokine IL-10 were not affected by PMA but were significantly down-regulated by HK E. coli. AP-1 activation was significantly increased $2 \mathrm{~h}$ after PMA exposure and continued to increase thereafter. In contrast, NF-KB responded to PMA exposure by a rapid up-regulation followed by a subsequent down-regulation. Increased intracellular $\mathrm{Ca}^{2+}$ concentrations countered the down-regulation of NF-kB by PMA, while similar treatment with calcium ionophore resulted in a reduced NF-KB activity following induction with HKE. coli. In order to further study NF$\mathrm{KB}$ activation, we considered two up-stream signalling proteins, PKC and BCl10. Phosphorylated-PKC levels increased in response to PMA and HKE. coli, while Bcl10 levels significantly decreased following PMA treatment. Using an NF-KB activation inhibitor, we observed complete inhibition of IL-6 expression while CXCL8 levels only decreased by $40 \%$ at the highest concentration. Treatment of Jurkat T-cells with PMA in the presence of JNK-inhibitor suppressed both CXCL8 and IL-6 while PKC-inhibitor primarily decreased CXCL8 expression.

Conclusion: The present study shows that NF-KB regulated IL- 6 but not CXCL8. This complex regulation of CXCL8 suggests that there is a need to further evaluate the signalling pathways in order to develop new treatment for diseases with elevated CXCL8 levels, such as AIDS and autoimmune diseases.

\section{Background}

Cytokines and chemokines are important in immune cell recruitment and in regulation of inflammatory responses [1]. T-cells produce a broad range of inflammatory mediators, including IL-2, IL-6, TNF and CXCL8, all of which are important in cell proliferation, differentiation, communication and initiation of inflammatory responses [2]. Elevated levels of pro-inflammatory cytokines and chemokines, such as TNF, IL-6 and CXCL8, are associated with several human diseases including cystic fibrosis

* Correspondence: per-erik.olsson@oru.se

1 Biology, Örebro Life Science Center, School of Science and Technology, Örebro University, SE-701 82 Örebro, Sweden

Full list of author information is available at the end of the article
[3-5], pulmonary fibrosis [6,7] and AIDS [8,9]. Induction of CXCL8 has been suggested to be mediated through NF- $\mathrm{KB}$ in cooperation with AP-1 $[10,11]$, however the precise mechanism is not fully elucidated, and treatment strategies aimed at inhibiting CXCL8 have failed [12]. Persistent production of IL-6 and CXCL8 leads to chronic inflammation and enhanced survival of lymphocytes increasing serum cytokine/chemokine levels. This forms the basis of several autoimmune disorders including plasmacytosis and hyperplasia [13]. To develop viable CXCL8 based treatment strategies, it is necessary to identify the signalling pathways regulating CXCL8 and determine how this is coupled to NF-kB, AP-1 and IL-6. 
The signalling pathways leading to NF- $\mathrm{BB}$ and AP-1 activation are overlapping, where both are involved in the induction and regulation of cytokines/chemokines. NF$\mathrm{KB}$ is activated in response to stress, such as oxidative stress, bacterial toxins, viruses and UV light [14], and is essential for differentiation, proliferation and survival of many cell types including T-lymphocytes [15]. AP-1 activation requires Fos (c-Fos, FosB, Fra-1, Fra-2) and Jun (cJun, v-Jun, JunB, JunD) through the formation of homoand hetero-dimers $[16,17]$, and regulates transcription of a broad range of genes involved in immune responses [18-21]. Both AP-1 and NF- $\mathrm{B}$ binding sites have been identified in the promoter region of IL- 6 and CXCL8 $[12,22]$, however, the mechanism by which these interleukins are regulated in T-cells is still not clear. CXCL8 is a $\mathrm{C}-\mathrm{X}-\mathrm{C}$ chemokine with properties enabling it to recruit T-cells and basophils and to activate neutrophils and monocytes [23]. IL-6 is a cytokine that possesses both pro- and anti-inflammatory characteristics and that plays a key role in haematopoiesis and acute-phase responses [24,25].

The present study suggests that the regulation of CXCL8 and IL-6 is uncoupled. Using Jurkat T-cells exposed to PMA and heat killed (HK) Escherichia coli MG1655 in combination with inhibitors of NF-kB, JNK and $\mathrm{PKC}$, we demonstrated that NF- $\mathrm{KB}$ regulates IL-6 expression while the regulation of CXCL8 more closely correlated to AP-1 activity. These results indicate that inhibition of NF- $\mathrm{kB}$ is not an effective strategy in countering the high CXCL8 activities in diseases such as cystic fibrosis, AIDS and pulmonary fibrosis.

\section{Results}

\section{Regulation of AP-1 and NF-KB activation}

The transcription factors NF-kB and AP-1 play key roles in the initiation of an inflammatory response by inducing the expression and secretion of chemokines and cytokines that attract and activate immune cells. However, the signal transduction pathways and subsequent inflammatory cytokine induction by these transcription factors is not fully elucidated. The present study is aimed at determining the involvement of AP-1 and NF- $\mathrm{kB}$ in cytokine induction and regulation. PMA treatment resulted in an up-regulation of AP-1 after $2 \mathrm{~h}$ exposure and continued to increase throughout the analysis period (figure 1a). HK E. coli treatment did not affect AP-1 activation in Jurkat $\mathrm{T}$-cells (figure 1b). To determine the involvement of associated pathways, we exposed cells to $\mathrm{Ca}^{2+}$ ionophore with or without PMA and observed a modest involvement of $\mathrm{Ca}^{2+}$ in PMA-dependent AP-1 activation (figure 1c) while $\mathrm{Ca}^{2+}$ alone did not alter AP-1 activity (data not shown). Furthermore, AP-1 activity decreased in a TCR-deficient Jurkat cell line when exposed to PMA compared to the parent cell line indicating that regulation of AP-1 was only partially $\mathrm{T}$-cell receptor dependent (figure $1 \mathrm{~d}$ ).

NF- $\mathrm{kB}$ levels showed a transient increase at $1 \mathrm{~min}$ after exposure to PMA (figure 2a). However, $1 \mathrm{~h}$ after exposure the NF- $\mathrm{kB}$ levels began to drop reaching the lowest levels by $6 \mathrm{~h}$, after which they increased again by $24 \mathrm{~h}$. Exposure of Jurkat T-cells to HK E. coli resulted in a dose-dependent NF- $\mathrm{kB}$ activation, with the highest activity observed at a relative concentration of $5 \times 10^{7} \mathrm{CFU} / \mathrm{ml}$ (figure $2 \mathrm{~b}$ ). The time-dependent activation of NF- $\mathrm{kB}$ by HK E. coli was assessed further using the optimal concentration obtained from figure $2 \mathrm{~b}$ and showed that the NF- $\mathrm{B}$ activity increased after $3 \mathrm{~h}$ of exposure (figure 2c). Furthermore, increased intracellular $\mathrm{Ca}^{2+}$ reversed the PMA dependent NF- $\mathrm{kB}$ inhibition (figure $2 \mathrm{~d}$ ) and reduced the HK E. coli-dependent NF-kB activation (figure 2e).

\section{Induction of inflammatory responses}

The ability of PMA and HK E. coli to induce an inflammatory response in Jurkat T-cells was evaluated using a multiplex cytokine assay following $24 \mathrm{~h}$ stimulation. The cytokine profile revealed an enhanced induction of the pro-inflammatory cytokines IL-2, IL-6, TNF and the chemokine CXCL8. The levels of the anti-inflammatory cytokine IL-10 were unaffected by PMA but were significantly decreased by HK E. coli (Table 1 ). These results confirmed that PMA and HK E. coli induced an inflammatory response in the Jurkat T-cells. It is interesting to note that PMA was 120-fold more effective at inducing CXCL8 than HK E. coli. PMA-dependent induction of $\mathrm{AP}-1$ and down-regulation of NF- $\mathrm{kB}$ suggests an involvement of AP-1 in CXCL8 regulation. Determination of the time course of cytokine induction in response to PMA showed that CXCL8 was already released between 2-6 h, while TNF and IL-6 were released between 6-24 h (figure $3)$. These results indicated that the cytokines were differentially regulated and that the release was not associated with the early transient induction of NF-kB. The temporal induction of AP-1 correlated to the CXCL8 levels and preceded the TNF and IL- 6 release. This suggests an association between CXCL8 release and AP-1 signalling.

\section{Cooperative induction of cytokines by AP-1 and NF-KB}

To further characterize the involvement of NF-kB in cytokine regulation, we treated cells with an NF- $\mathrm{kB}$ activation inhibitor (NAI). The results showed that NAI selectively down-regulated NF- $\mathrm{kB}$ activation (figures $4 \mathrm{a}$ and $4 \mathrm{~b}$ ) and did not alter AP-1 activity (figures 4c and 4d). Exposure of Jurkat T-cells to NAI resulted in a modest reduction of CXCL8 following PMA exposure, while it did not alter the CXCL8 release following HK E. coli exposure (figure 5a). NAI did not affect TNF expression (figure $5 \mathrm{~b}$ ) indicating that $\mathrm{NF}-\mathrm{kB}$ is not the main regulator of CXCL8 or TNF following either PMA or HK E. coli 


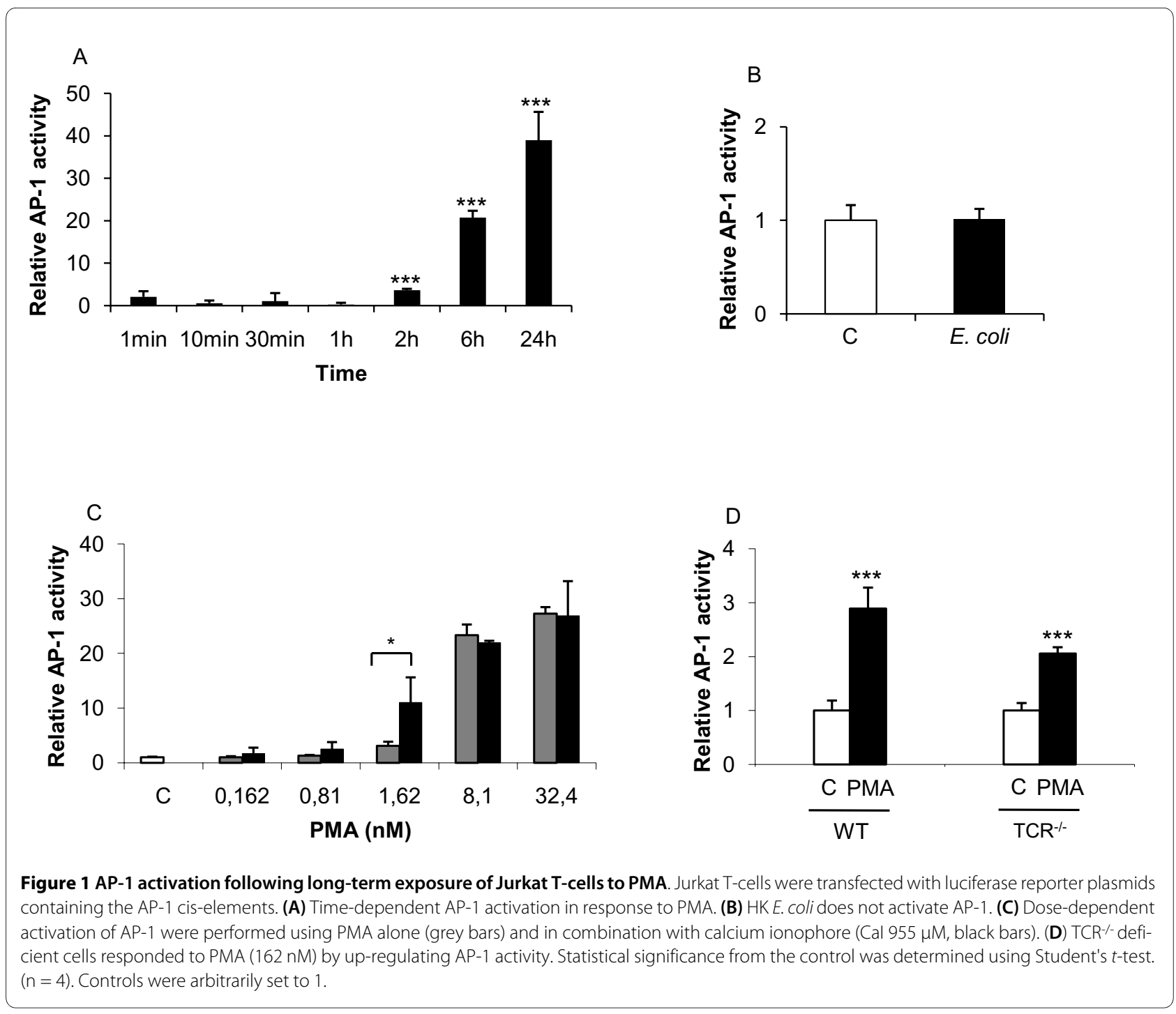

exposure in Jurkat T-cells. In contrast, NAI resulted in a complete inhibition of IL-6 following PMA exposure and a $45 \%$ inhibition following HK E. coli exposure (figure 5c), suggesting an involvement of NF- $\mathrm{KB}$ in IL-6 regulation.

$\mathrm{Ca}^{2+}$ was observed to increase AP-1 activity (figure 1c) and reduce NF- $\mathrm{KB}$ activity (figure 2e); therefore, we exposed T-cells to a PKC inhibitor together with PMA to determine its effect on cytokine expression. Inhibition of PKC reduced CXCL8 release from $7 \mathrm{ng} / \mathrm{ml}$ to $3 \mathrm{ng} / \mathrm{ml}$ while it had a modest effect on IL-6 and TNF (figure 6ac). This prompted us to test the effect of JNK inhibition on PMA-induced cytokine expression. JNK is involved in the regulation of a multitude of different transcription factors, including the phosphorylation and activation of c-Jun, c-Fos and p53, leading to cellular apoptosis [26]. Inhibition of the JNK pathways resulted in a down-regulation of both CXCL8 and IL-6, while no clear effect was observed on TNF expression (figure 6a-c). Analysis of
mRNA levels using RT-qPCR (table 2) showed that PMA induced both $i l-6$ and $c x c l 8$ mRNA (5.1-fold and 111.8 fold respectively). Addition of the NF- $\mathrm{kB}$ inhibitor NAI and the JNK inhibitor reduced the il-6 expression below basal levels. In contrast, while the $c x c l 8$ levels were suppressed by the same treatments the levels remained elevated above basal level.

\section{NF-KB inhibition due to PKC-dependent Bcl10 degradation}

Western blot analysis revealed an up-regulation of phosphorylated-PKC after $24 \mathrm{~h}$ treatment of Jurkat T-cells with PMA or HK E. coli (figure $7 \mathrm{a}$ ), while IкB $\beta$ levels remained unaffected (figure $7 \mathrm{~b}$ ). Bcl10 is a signalling protein that acts upstream of NF-kB in concert with CARMA1 and MALT1 and has been suggested to directly regulate NF- $\kappa B$ activity in T-cells [27]. Therefore, Bcl10 activation was evaluated in both control and PMA stimulated cells after $10 \mathrm{~min}, 1 \mathrm{~h}, 6 \mathrm{~h}$, and $24 \mathrm{~h}$ using western blot analysis. The Bcl10 levels decreased following treat- 


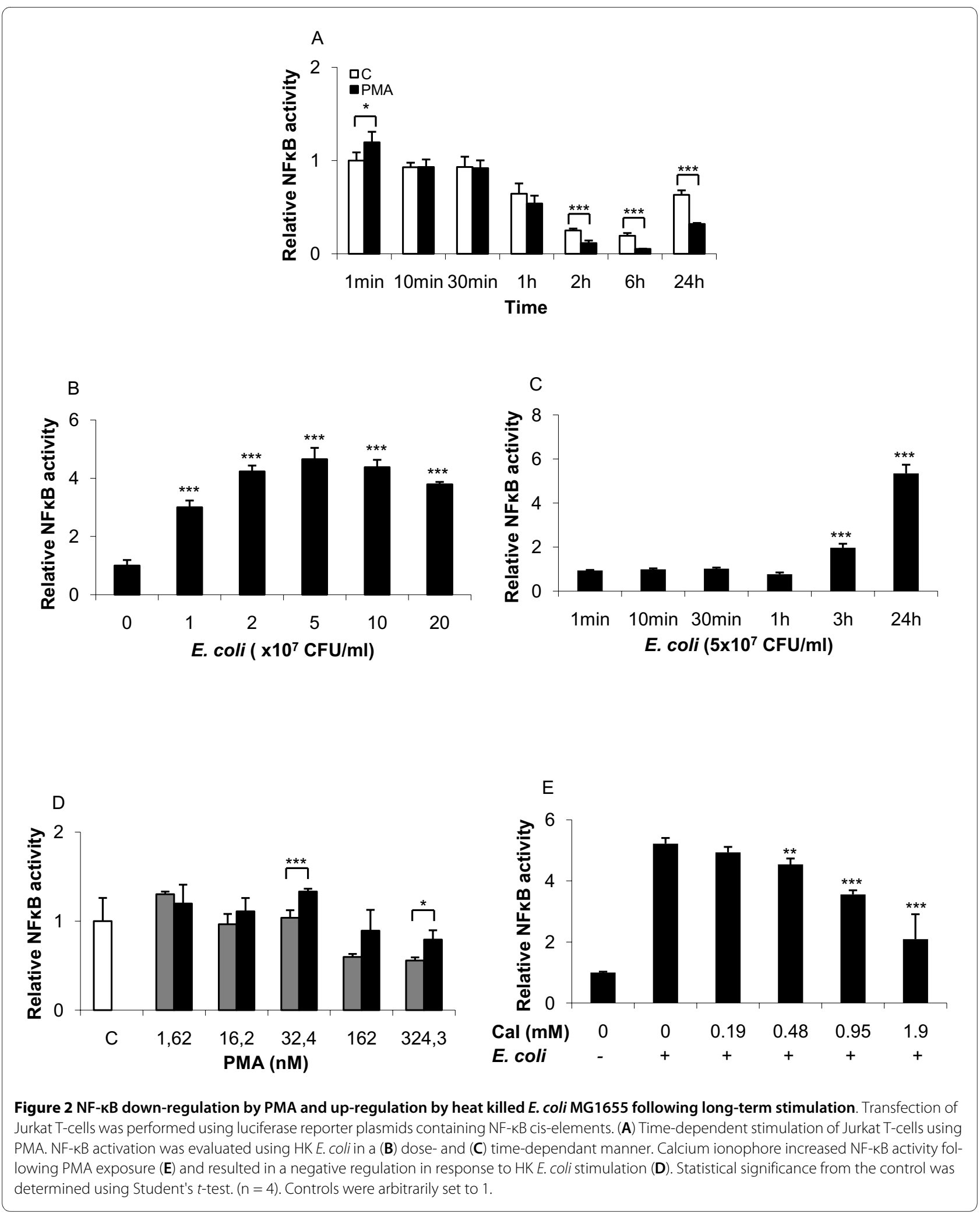



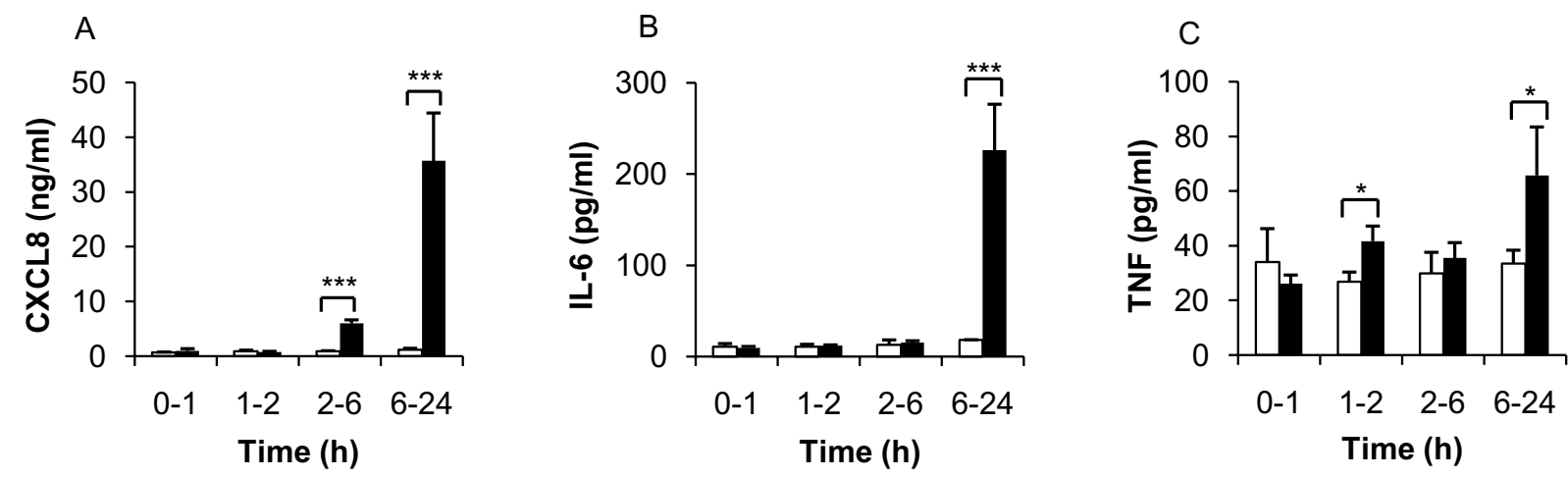

Figure 3 CXCL8, IL-6 and TNF expression following long-term stimulation with PMA. Jurkat T-cells were either treated with media (white bars) or stimulated with PMA (black bars) and incubated for $1 \mathrm{~h}, 2 \mathrm{~h}, 6 \mathrm{~h}$ and $24 \mathrm{~h}$. Aged media was added following each centrifugation step representative to the stimulation time (see Materials and methods). Cytokine levels (A) CXCL8, (B) IL-6 and (C) TNF were detected by ELISA. Statistical significance from the control was determined using Student's $t$-test. $(n=3)$.

ment with PMA, while in control cells, Bcl10 returned to higher levels by $24 \mathrm{~h}$ (figure $7 \mathrm{c}$ ). This suggests that Bcl10 is involved in the PMA dependent inhibition of NF-kB activation.

\section{Discussion}

NF- $\mathrm{kB}$ and AP-1 are critical regulators of inflammatory responses, proliferation and differentiation of T-cells [2830], however, the signal transduction and subsequent cytokine/chemokine expression is not fully understood. The aim of the present study was to investigate IL- 6 and CXCL8 regulation by NF- $\mathrm{kB}$ and AP-1 in Jurkat T-cells.

Our results demonstrated that PMA induced AP-1 activation, indicating a specific activation of the MAPK pathway. Furthermore, we demonstrated that PMA dependent AP-1 activation in T-cells was delayed $(>2 \mathrm{~h})$ and increased following long-term treatment. MAPK is one of the main signalling pathways in T-cells that regulate cell- and transcriptional activation [31,32]. Several studies $[20,33,34]$ have indicated the importance of AP-1 in T-cell activation and the induction of inflammatory responses [35], including pro-inflammatory cytokine release. In contrast to $\mathrm{AP}-1, \mathrm{NF}-\mathrm{\kappa} B$ activity rapidly increased (1 min) during PMA exposure followed by a down-regulation to the lowest levels at $6 \mathrm{~h}$. This is in line with Park and colleagues [36] who demonstrated a rapid increase in NF- $\mathrm{KB}$ activity following short-term stimulation with PMA, but prolonged challenge resulted in a persistent inhibition of NF-kB. They showed that the inhibition of NF- $k B$ was due to PKC-dependent degradation of IKB kinase $\beta$ and $\gamma$ in response to PMA. Interestingly, the HK E. coli exposure induced NF- $\mathrm{KB}$ activation without affecting AP-1 activity. Wang and colleagues [37] reported an elevated inflammatory response by obtaining expression of IL-6 following the exposure of T-cells to peptidoglycan. Reduction in NF- $\mathrm{kB}$ by calcium ionophore following HK E. coli stimulation may be due to the $\mathrm{Ca}^{2+}$ binding protein calmodulin $(\mathrm{CaM})$, which has been shown to negatively regulate $\mathrm{c}-\mathrm{Rel}$ when activated [38]. The regulation of NF- $\mathrm{kB}$ and $\mathrm{AP}-1$ observed in the present study was in agreement with earlier studies.

T-cells produce a broad range of pro- and anti-inflammatory cytokines, including IL-2, IL-6, CXCL8, TNF and IL-10, in response to infections or other stress factors [39]. The assessment of Jurkat T-cell inflammatory responses (Table 1) revealed an enhanced IL-2 expression

Table 1: Jurkat T-cells were stimulated with 162 nM PMA and $5 \times 10^{7}$ CFU/mI HK E. coli for 24 h.

\begin{tabular}{llll}
\hline & C & HK E. coli & PMA \\
\hline IL-2 & & \\
IL-6 & $0.25 \pm 0.27$ & $0.95 \pm 0.06^{* *}$ & $1.75 \pm 0.16^{* * *}$ \\
CXCL8 & $6.65 \pm 0.2$ & $27.275 \pm 1.47^{* * *}$ & $50.33 \pm 2.64^{* * *}$ \\
IL-10 & $38.45 \pm 5.02$ & $253.08 \pm 13.42^{* * *}$ & $230,000^{* * *}$ \\
TNF & $13.07 \pm 0.64$ & $4.10 \pm 0.11^{* * *}$ & $12.99 \pm 0.92$ \\
\hline
\end{tabular}

Cytokine levels were determined using multiplex assays. Concentrations are given as $\mathrm{pg} / \mathrm{ml}$ for each group (mean value $\pm S D, n=3$ ). Statistical significance from the control (C) was determined using Student's $t$-test. 


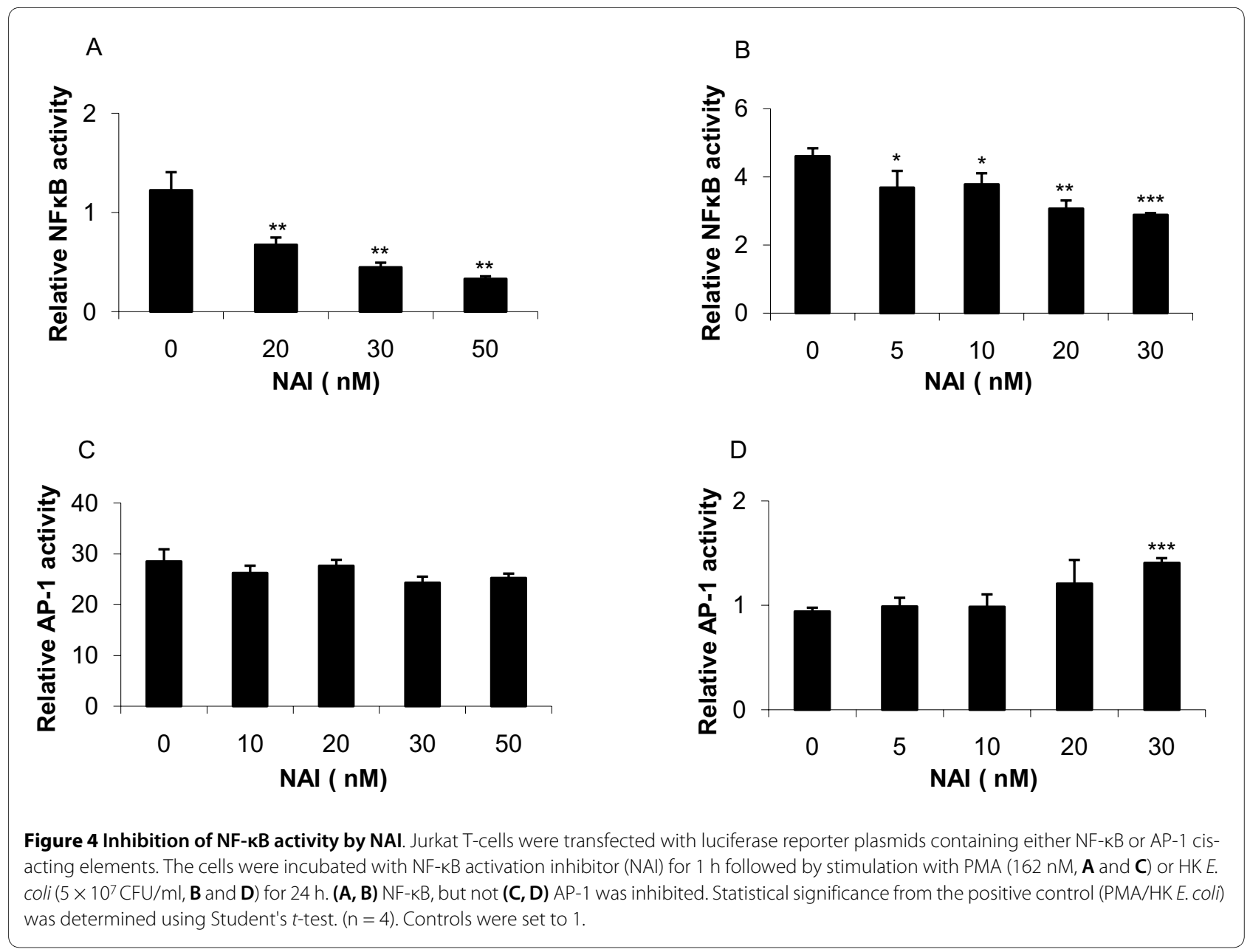

upon exposure to PMA or HK E. coli due to PKC activation [40]. In addition to the transcription factor NF- $\mathrm{KB}$, AP-1 binding sites have been identified in the IL- 6 promoter region, indicating multiple regulation [22]. AP-1 and NF- $\mathrm{kB}$ have also been demonstrated to regulate CXCL8 expression during induction of inflammatory responses in T-cells [12]. Furthermore, IL-6 and CXCL8 gene-expression is associated with an early immune response in Jurkat T-cells [41]. In the present study, both PMA and HK E. coli resulted in comparable increases in IL-6 while PMA was more potent at activating CXCL8 release. PMA and HK E. coli treatment also induced TNF expression. TNF is one of the first cytokines induced by T-cells [42] and its expression is regulated by calcineurin, NFAT and ATF-2/Jun [20]. However, PMA-stimulated Jurkat T-cells showed no difference in IL-10 expression indicating an induced inflammatory response. HK E. coli treatment resulted in a significant reduction of IL-10 expression. The anti-inflammatory cytokine IL-10 is known to inhibit T-cell activation, proliferation and the expression of pro-inflammatory cytokines, such as IL-2,
IL-5 and INF- $\gamma[39,43]$ and regulate inflammatory responses by inducing T-cell anergy [44].

The time course analysis of cytokine expression showed a correlation between AP-1 and the chemokine CXCL8 where CXCL8 expression was significantly elevated already at 2-6 h after PMA exposure. The CXCL8 expression did not correlate with the early NF- $\mathrm{kB}$ activation (1 min) or with the down-regulation of NF- $\kappa B$ at $2 \mathrm{~h}$ post exposure. Both IL-6 and TNF expression were up regulated between 6-24 h. During this period, NF-kB increased from its minimum level at $6 \mathrm{~h}$. PKC has been shown to be associated with the activation of AP-1, but not with NF-kB activation of the IL-2 promoter [45]. Mutation of the NF- $\mathrm{kB}$ site did not affect IL-2 expression, whereas mutation of the AP-1 site or PKC depletion almost revoked IL-2 release. These observations indicate that the MAPK pathway and the transcription factor AP1 play an important role in the induction of inflammatory responses in Jurkat T-cells [12,20,22]. The obtained results signify that CXCL8 was primarily regulated through the MAPK pathway. 


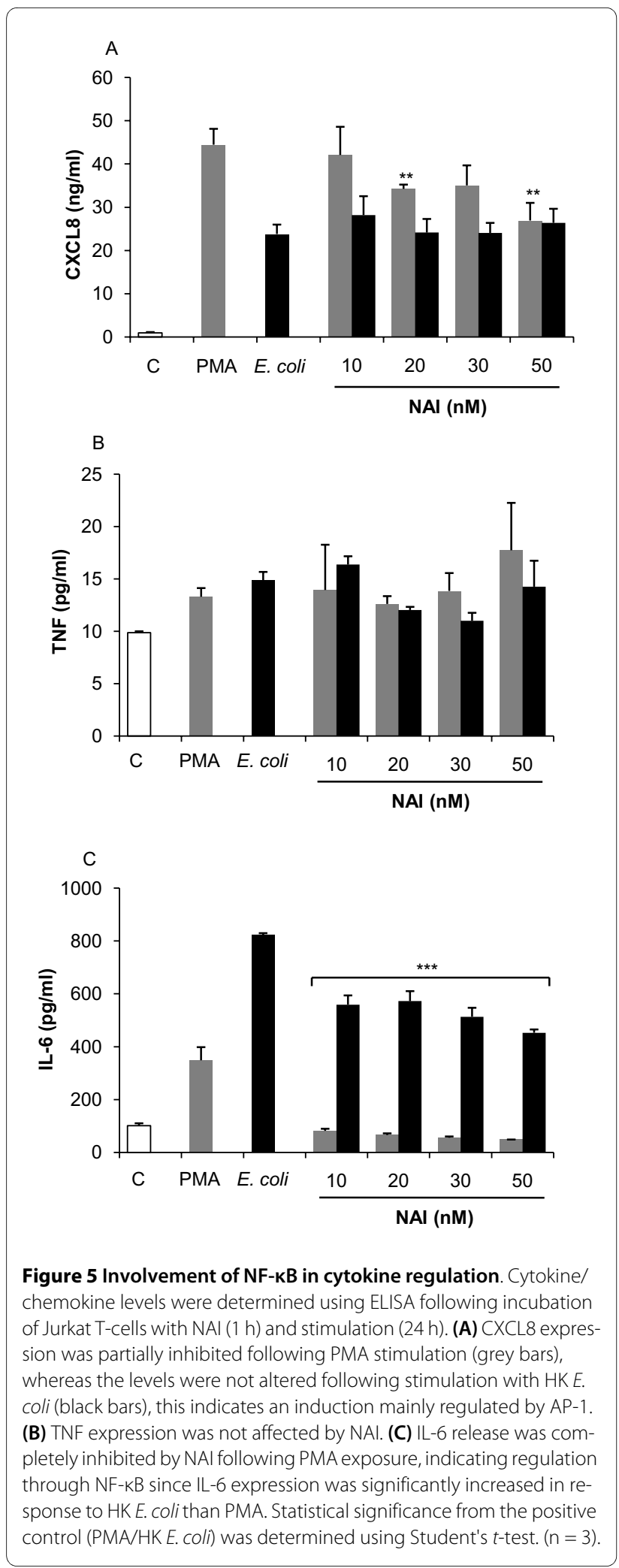

The NF- $\mathrm{kB}$ activation inhibitor (NAI) showed specificity against NF- $\mathrm{KB}$ and resulted in a complete IL-6 inhibition following induction with PMA and significant IL-6 reduction after HK E. coli treatment. CXCL8 was highly

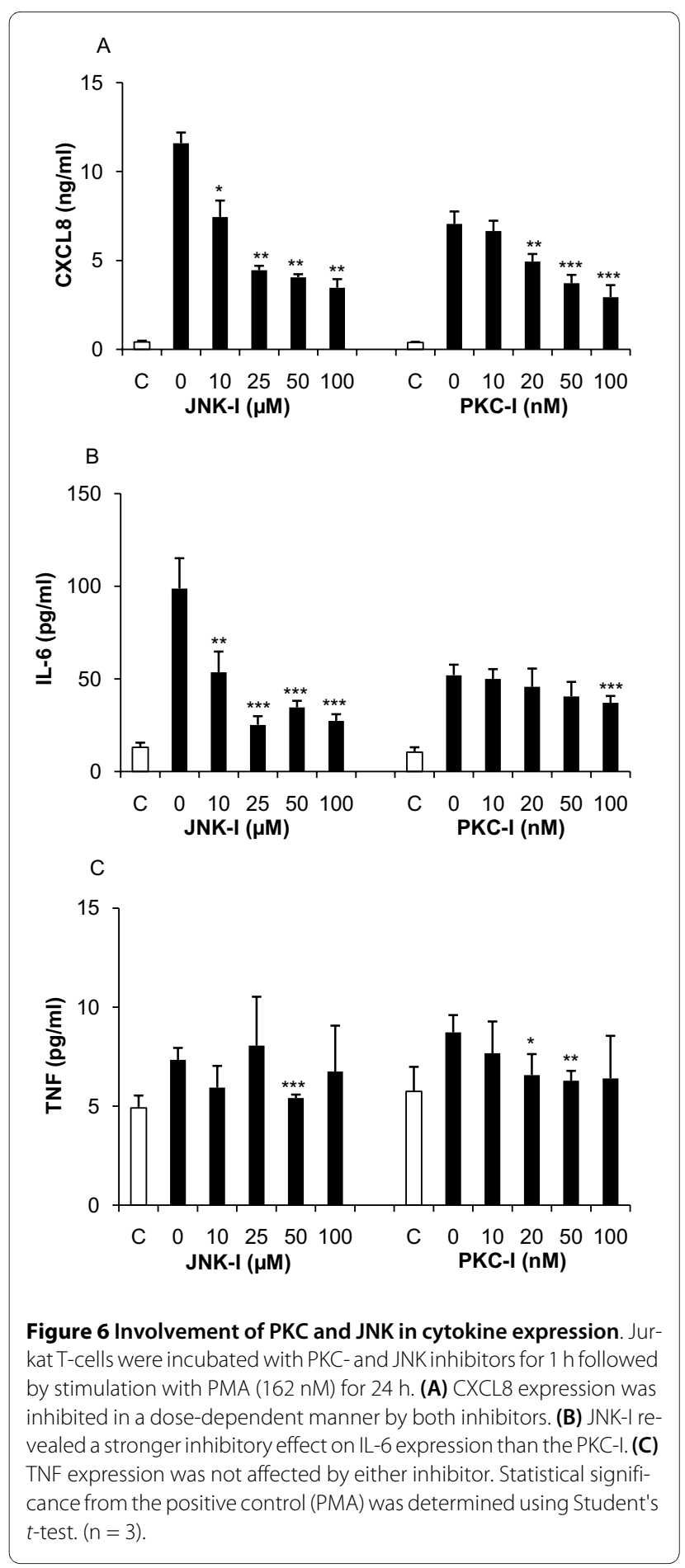

up regulated by PMA and the addition of NAI resulted in a minor reduction in CXCL8 expression. Furthermore, CXCL8 expression was not affected by NAI following HK E. coli treatment, indicating a lack of correlation between CXCL8 and NF-kB. Further analysis of CXCL8 expression revealed a down-regulation by PKC- and JNK- inhibitors, suggesting an involvement of AP-1 via PKC and JNK, respectively. Analysis of gene expression further 
Table 2: Jurkat T-cells were treated with $10 \mathrm{nM}$ NAI, $10 \mu \mathrm{M}$ JNK-I or10 nM PKC-I for $2 \mathrm{~h}$ followed by induction with $162 \mathrm{nM}$ PMA for $24 \mathrm{~h}$.

\begin{tabular}{llllll}
\hline & C & PMA & NAI & JNK-I & PKC-I \\
\hline IL-6 & & & & \\
CXCL8 & $11.7 \pm 2.4$ & $63.6 \pm 11.9$ & $3.3 \pm 4.0^{*}$ & $2.7 \pm 2.2^{* *}$ & $39.0 \pm 20.8$ \\
\hline
\end{tabular}

Gene expression was determined using RT-qPCR. The $\mathrm{Ct}$ values were normalized against $18 \mathrm{~S}$. Statistical significance from the positive control (PMA) was determined using Student's $t$-test. Concentrations are given as $\mathrm{fg} / \mathrm{ml}$, values are presented as mean $\pm \mathrm{SEM}, \mathrm{n}=3$.

confirmed that il-6 and cxcl8 were upregulated by PMA. Expression of $i l-6$ dropped below basal levels following inhibition of NF- $\mathrm{kB}$ and JNK whereas cxcl8 remained elevated above basal levels (16.5-fold and 7.1-fold respectively) following the same treatment. Furthermore, inhibition of PKC did not result in a significant decrease

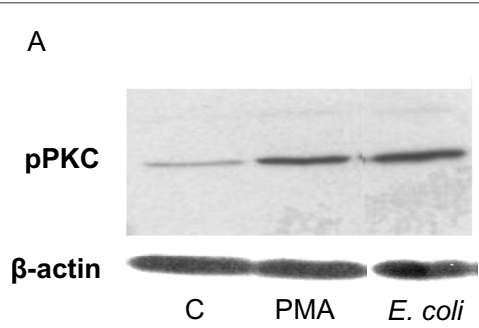

B

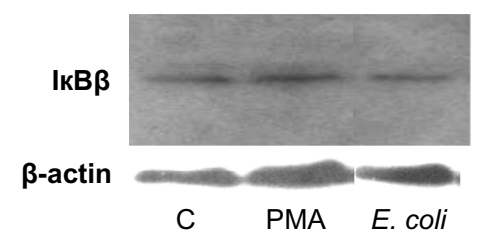

C

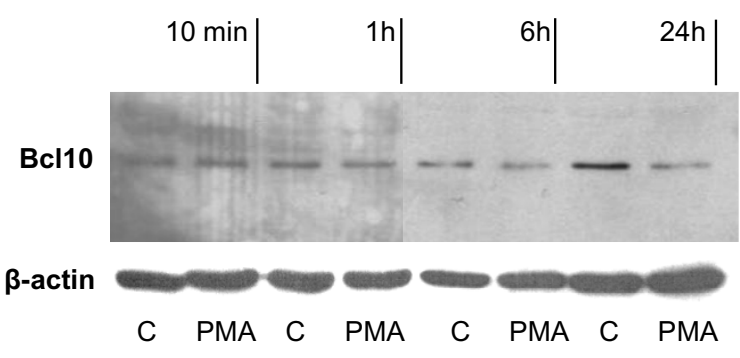

Figure 7 NF-KB inhibition by PMA correlated to PKC-dependent Bcl10 degradation. Levels of intracellular protein were assessed following $24 \mathrm{~h}$ stimulation with PMA $(162 \mathrm{nM})$ or HK E. coli $\left(5 \times 10^{7} \mathrm{CFU} /\right.$ $\mathrm{ml}$ ). (A) Phospho-PKC increased in response to PMA and HK E. colistimulation. (B) $\mid \mathrm{KB}$ decreased following stimulation with HK E. coli indicating NF-KB activation. (C) BCl10 activation was inhibited following longterm stimulation with PMA, which explains the inhibitory effect of PMA on NF-KB activation. $\beta$-actin was used as a loading control. $(n=3)$. of $i l-6$ or $c x c l 8$, which is in accordance with protein data (figure 6). These results suggest that NF- $\mathrm{kB}$ is involved in IL- 6 regulation and release while it is not required for the expression of CXCL8 in Jurkat T cells.

The transcription factor NF- $\mathrm{KB}$ is responsible for a rapid immune response which is followed by an increase in transcription of I $\kappa B$ thus inhibiting NF- $\kappa B$ [46]. Activation of NF-KB in Jurkat T-cells is dependent on Bcl10 activation, which in turn is regulated by PKC. Recent studies have established the importance of a protein complex consisting of CARMA1, Bcl10 and MALT1 (CBM), in the induction of NF- $\mathrm{KB}$. Investigating Bcl10, Scharschmidt and colleagues [47] demonstrated that it is a critical regulator of NF- $\mathrm{kB}$ activity. Down-regulation of Bcl10 from signals transduced via the TCR/CD28 and PKC resulted in a concomitant down-regulation of NF$\kappa B$. They suggested that Bcl10 is initially activated by $\mathrm{TCR} / \mathrm{PKC}$ but that continued activation $(>1 \mathrm{~h})$ promotes its degradation. Narayan and colleagues [27] suggested that deletion in any of the three CBM complex proteins impairs antigen-receptor dependent activation of NF- $\kappa B$. They showed that NF- $\mathrm{kB}$ activation via Akt requires CARMA1 and acts in cooperation with PKC following short-term exposure (30 min) of Jurkat T-cells with PMA. Akt phosphorylates and thus activates Bcl10. These studies indicate that PKC is crucial for NF- $\mathrm{KB}$ activation following short-term treatment through signals via membrane bound receptors such as the TCR and the costimulatory receptor CD28. Thus, the CBM complex proteins play a key role in this signalling process. PMA diffuses into the cytosol and directly activates PKC since it is an analogue to diacylglycerol [48]. Several studies have demonstrated that inhibition of PKC blocks NF- $\mathrm{KB}$ and AP-1 activity, suggesting a direct regulation of these transcription factors by PKC $[49,50]$. PKC is activated at an early stage following T-cell stimulation and is therefore an important regulator of downstream inflammatory signalling pathways leading to cytokine expression [50]. We have shown that phosphorylated-PKC is up regulated in response to PMA and HK E. coli, indicating an association between PKC and the transcription factors AP-1 and NF-кB. Bcl10 levels were down-regulated following extended treatment of Jurkat T-cells with PMA. In the 
control groups, a loss of Bcl10 occurred after $6 \mathrm{~h}$, followed by an increase after $24 \mathrm{~h}$, which is in accordance with the observed NF-kB activity (figure 7). These results are supported by an earlier study [47], demonstrating that prolonged PKC activation by PMA leads to an inhibition of Bcl10 and NF-kB.

It has been shown that NF- $\mathrm{kB}$ is an important transcription factor complex involved in almost every aspect of cell regulation including apoptosis, differentiation, proliferation and initiation of immune responses [51-53]. $\mathrm{NF}-\kappa \mathrm{B}$ is constitutively active in many human malignancies, which makes it an attractive therapeutic target [54]. Elevated CXCL8 levels during chronic inflammation result in an enhanced recruitment of immune cells to the site of infection, which may lead to the development of autoimmune diseases following secretion of pro-inflammatory cytokines. In HIV infected persons, serum CXCL8 levels are elevated and this could recruit more Tcells potentially leading to a more rapid progression of the disease since there will be more T-cells available to infect.

\section{Conclusion}

In the present study, IL-6 release was found to be associated with NF-kB activity while CXCL8 release more closely correlated with AP-1 activity. Treatment of Jurkat T-cells with PMA was more potent than HK E. coli at elevating the CXCL8 levels. PMA induced AP-1 activation and down-regulated NF- $\mathrm{KB}$ while HK E. coli up-regulated NF- $\kappa B$ without affecting AP-1 activity. In addition, the temporal induction pattern of AP-1 correlated to the release of CXCL8 while IL-6 followed the NF- $\mathrm{kB}$ activity. Likewise, blocking NF- $\kappa B$ activation resulted in a complete inhibition of IL- 6 while the CXCL8 levels remained elevated as shown both at the protein and mRNA level. Furthermore, the CXCL8 release was down-regulated by inhibition of JNK activity. The present study indicates that in Jurkat T-cells, IL-6 is regulated through NF- $k B$ while CXCL8 regulation is independent of NF- $\mathrm{kB}$ and closely associated with AP-1 activation.

\section{Materials and methods \\ Chemicals}

The following chemicals were used in the present study: PMA (Phorbol 12-myristate 13-acetate, (Sigma \#P1585, USA)); NF- $k B$ activation inhibitor (NAI), (InSolution ${ }^{\mathrm{nu}}$ NF- $k B$ Activation Inhibitor, Calbiochem \#481407, USA); JNK inhibitor, (InSolution ${ }^{\text {tw }}$ JNK Inhibitor II, Calbiochem \#420128, USA); PKC Inhibitor, (InSolution ${ }^{\mathrm{mm}}$ Bisindolylmaleimide I, Calbiochem \#203293, USA); Calcium Ionophore, (Calcium Ionophore A23187 mixed calcium magnesium salt, Sigma \#C5149, USA).

\section{Heat killed (HK) Escherichia coli}

E. coli MG1655 were grown on Luria-Bertani (LB) agar and incubated at $37^{\circ} \mathrm{C}$ overnight. One colony was inoculated into $10 \mathrm{ml} \mathrm{LB}$ broth and incubated on a shaker $(200$ $\mathrm{rpm})$ at $37^{\circ} \mathrm{C}$ overnight. The bacteria were centrifuged for $10 \mathrm{~min}$ at $3000 \times \mathrm{g}$, washed with $3 \mathrm{ml}$ phosphate buffered saline (PBS; $8 \mathrm{~g} \mathrm{NaCl}, 1.16 \mathrm{~g} \mathrm{Na}_{2} \mathrm{HPO}_{4}, 0.2 \mathrm{~g} \mathrm{KH}_{2} \mathrm{PO}_{4}, 0.2$ $\mathrm{g} \mathrm{KCl}, \mathrm{pH} 7)$ and resuspended in $50 \mu \mathrm{l}$ PBS. The bacteria were killed by heating to $70^{\circ} \mathrm{C}$ for $1 \mathrm{~h}$. To ensure that the bacteria were killed; $10 \mu \mathrm{l}$ of the heat-killed suspension was spread on a LB plate and incubated overnight at $37^{\circ} \mathrm{C}$.

\section{Cell culturing, transfection and stimulation}

Jurkat T-cells (wild type and TCR deficient- $\mathrm{TCR}^{-/}$) were maintained in 90\% RPMI 1640 medium (PAA laboratories, Austria) with $1.5 \mathrm{mM}$ L-glutamine (Invitrogen, USA), $10 \%$ foetal bovine serum (Invitrogen, USA) and 1\% antibiotic-antimycotic (Invitrogen, USA) and incubated in a stable environment of $5 \% \mathrm{CO}_{2}$ at $37^{\circ} \mathrm{C}$.

The cells were centrifuged at $1000 \times \mathrm{g}$ for $8 \mathrm{~min}$ and resuspended in fresh media to a final cell density of $1.6 \times$ $10^{7} \mathrm{cells} / \mathrm{ml}$ in a 24-well plate. Reporter plasmid (pNFkBLuc, pAP1 (PMA)-TA-Luc, pNFкB-SEAP), internal control plasmid (pRL) (Promega, USA) and lipofectamine 2000 (Invitrogen, USA) were added to each well at 0.54 $\mu \mathrm{g} /$ well, $0.06 \mu \mathrm{g} /$ well and $1.5 \mu \mathrm{l} /$ well, respectively. Initially, the reporter plasmid and pRL were mixed separately with OptiMEM (Gibco, USA). After $5 \mathrm{~min}$ of incubation at room temperature, lipofectamine 2000 was added and the mixture was incubated further for $20 \mathrm{~min}$ at room temperature. The transfection was allowed to proceed overnight at $37^{\circ} \mathrm{C}$, after which, the cells were centrifuged, the media removed and fresh pre-warmed media added. The cells were pre-incubated with NF-kB, JNK and PKC inhibitors and stimulated in 24-well plates with different concentrations of PMA, HK E. coli MG1655 and Calcium Ionophore A23187.

The cells were lysed and luciferase activity (NF- $\mathrm{kB}$ and AP-1) was measured using the Dual-Luciferase reporter assay system (Promega, USA) according to the manufacturer's instructions on a TD 20/20 luminometer (Turner Designs, Sunnyvale, CA). Secreted alkaline phosphatase (NFkB-SEAP, figure 4a, b) levels were measured using Great EscAPe $^{\mathrm{m}}$ SEAP Detection Kit (Clontech, USA).

\section{Multiplex cytokine assay}

Quantification of the levels of cytokines IL-2, IL-6, IL-10 and TNF and the chemokine CXCL8 was performed on culture supernatants using multiplexed biomarker immunoassay kits according to manufacturer's instructions (Bio-Rad Laboratories, Hercules, CA). A Bio-Plex ${ }^{\mathrm{mt}} 200$ readout System was used (Bio-Rad), which utilizes 
Luminex ${ }^{\circ} \mathrm{xMAP}^{\mathrm{mw}}$ fluorescent bead-based technology (Luminex Corp., Austin). Levels were automatically calculated from standard curves using Bio-Plex Manager software (v.4.1.1, Bio-Rad).

\section{Enzyme-linked immunosorbent assay (ELISA)}

ELISA was performed on supernatants from challenged Jurkat T-cells to quantify IL-6, CXCL8 and TNF (BD OptEIA Human IL-6 Elisa Set, BD OptEIA Human CXCL8 Elisa Set and BD OptEIA Human TNF Elisa Set, Biosciences, USA) according to the manufacturer's instructions. Briefly, Jurkat T-cells were stimulated with PMA $(162 \mathrm{nM})$ for $1 \mathrm{~h}$, centrifuged $(1000 \times \mathrm{g}, 8 \mathrm{~min})$ and the supernatants were collected and stored at $-80^{\circ} \mathrm{C}$ until use. Following centrifugation, the cells were resuspended in $1 \mathrm{~h}$ aged media, where cells have been grown in, containing PMA. The same procedure was performed to collect media after $2 \mathrm{~h}$ and $6 \mathrm{~h}$. The final collection of media was performed after $24 \mathrm{~h}$.

\section{Western blot analysis}

Following stimulation, Jurkat T-cells were centrifuged at $1000 \times \mathrm{g}$ for $8 \mathrm{~min}$ and lysed on ice for $2 \mathrm{~h}$ using sodium hydroxide with the addition of a protease inhibitor cocktail (Roche, Mannheim). The cells were further centrifuged at $8000 \times \mathrm{g}, 4^{\circ} \mathrm{C}$ for $10 \mathrm{~min}$ and the supernatants were transferred to new tubes. Cytoplasmic proteins $(\sim 8$ $\mu \mathrm{g})$ were separated by SDS-PAGE (10\%) followed by western blotting using anti-ІкB $\beta$, phospho-PKC (pan) $(\zeta$ Thr410)(190D10), anti-Bcl10 (Cell Signalling Technology, Boston) and beta-actin (Abcam, Cambridge). Detection was performed following incubation with $\mathrm{ECL}^{\mathrm{mw}}$ Anti-rabbit IgG, horseradish peroxidase linked whole antibodies (Amersham Biosciences, Buckinghamshire) and developed using ECL ${ }^{\mathrm{ma}}$ Western Blotting Detection Reagents (GE Healthcare, UK).

\section{RNA extraction}

Jurkat T-cells were treated with NF- $\mathrm{kB}$, JNK and PKC inhibitors for $2 \mathrm{~h}$ in 6 -well plates followed by stimulation with $162 \mathrm{nM}$ PMA for $24 \mathrm{~h}$. At sampling the cells were pelleted followed by RNA extraction using $100 \mu \mathrm{l}$ TRIreagent (Sigma, USA). This was followed by addition of $100 \mu \mathrm{l} \mathrm{chloroform}$ /isoamylalcohol (24/1). The solutions were mixed by vortexing followed by centrifugation at $12,000 \mathrm{rpm}$ for $15 \mathrm{~min}$ at $4^{\circ} \mathrm{C}$. The upper phase was transferred to a new tube followed by addition of $100 \mu \mathrm{l}$ isopropanol and incubated at room temperature for $10 \mathrm{~min}$. RNA was then pelleted by centrifugation at $12,000 \mathrm{rpm}$ for $15 \mathrm{~min}$ at $4^{\circ} \mathrm{C}$ and washed with $70 \%$ ethanol. The RNA pellet was dissolved in $25 \mu \mathrm{l}$ RNase free water and the yield and ratio $\left(\mathrm{A}_{260} / \mathrm{A}_{280}\right)$ was determined using NanoVue (GE Healthcare, UK). The samples were stored at $80^{\circ} \mathrm{C}$ until further use.

\section{Reverse transcription quantitative PCR (RT-qPCR)}

RT-qPCR was used to determine gene expression levels of il-6 and $\mathrm{cxcl} 8$ in response to PMA following inhibition of NF- $\mathrm{KB}$, JNK and PKC. The following primer sequences were used, il-6: forward- TGTGAAAGCAGCAAAGAGGCACTG, reverse- ACAGCTCTGGCTTGTTCCTCACTA; cxcl8: forward- ACCACACTGCGCCAAC ACAGAAAT, reverse- AAACTTCTCCACAACCCTCTGCAC. Thermocycling conditions for CYBR Green (Quanta, USA) consisted of a denaturation step for 10 min at $95^{\circ} \mathrm{C}$ followed by 60 cycles of $95^{\circ} \mathrm{C}$ for $1 \mathrm{~s}$ and $60^{\circ} \mathrm{C}$ for 30s. Gene expression was analysed using Stratagene $\left(\mathrm{Mx} 3000 \mathrm{p}^{\mathrm{m}} \mathrm{)}\right.$ (AH diagnostics). The obtained $\mathrm{Ct}$ values were normalized against $18 \mathrm{~S}$. Initially, all measured $18 \mathrm{~S}$ $\mathrm{Ct}$ values were used to calculate a mean $\mathrm{Ct}$ value that was used to determine the $\Delta \mathrm{Ct}$ values for each sample. Gene expression patterns for $i l-6$ and $c x c l 8$ were then normalized with regard to the samples $18 \mathrm{~S} \Delta \mathrm{Ct}$.

\section{Statistical analysis}

Statistical significant differences were determined using two-tailed Student's $t$-test ("p $<0.05$; ${ }^{* *} \mathrm{p}<0.01$; ${ }^{* * * *} \mathrm{p}<$ $0.001)$.

\section{Abbreviations \\ PKC: protein kinase $C_{\text {; }}$ TCR: $T$ cell receptor; CARMA1: caspase recruitment domain-containing membrane-associated guanylate kinase protein-1; Bcl10: B-cell chronic lymphocytic leukemia/lymphoma 10; MALT1: mucosa associated lymphoid tissue lymphoma translocation gene 1 .}

\section{Authors' contributions}

HK participated in the design of the study and conducted the lab work. JJ participated in the design of the study and the multiplex assays. PEO coordinated the study and participated in the design of the study. All authors participated in writing, reading and approving the final manuscript.

\section{Acknowledgements}

We thank Kelly Summers (LHRI, Canada) for performing cytokine multiplex assays and John McCormack (University of Western Ontario, London, Ontario, Canada) for his kind gift of TCR ${ }^{-/}$Jurkat T-cells. This study was funded by The Knowledge Foundation, Sweden and National Science and Engineering Research Council, Canada.

\section{Author Details}

'Biology, Örebro Life Science Center, School of Science and Technology, Örebro University, SE-701 82 Örebro, Sweden and 2The Lawson Health Research Institute and Department of Microbiology and Immunology, University of Western Ontario, London, Ontario, N6A 4V2 Canada

Received: 7 September 2009 Accepted: 27 May 2010 Published: 27 May 2010

\section{References}

1. Gonzalo JA, Lloyd CM, Kremer L, Finger E, Martinez AC, Siegelman MH, Cybulsky M, Gutierrez-Ramos JC: Eosinophil recruitment to the lung in a murine model of allergic inflammation. The role of T cells, chemokines, and adhesion receptors. J Clin Invest 1996, 98:2332-45.

2. Wang J, Shannon MF, Young IG: A role for Ets1, synergizing with AP-1 and GATA-3 in the regulation of IL-5 transcription in mouse Th2 lymphocytes. Int Immunol 2006, 18:313-23.

3. Carpagnano GE, Barnes PJ, Geddes DM, Hodson ME, Kharitonov SA: Increased leukotriene B4 and interleukin- 6 in exhaled breath condensate in cystic fibrosis. Am J Respir Crit Care Med 2003, 167:1109-12. 
4. Kube D, Sontich U, Fletcher D, Davis PB: Proinflammatory cytokine responses to $\mathrm{P}$. aeruginosa infection in human airway epithelial cell lines. Am J Physiol Lung Cell Mol Physio/ 2001, 280:L493-502.

5. Stecenko AA, King G, Torii K, Breyer RM, Dworski R, Blackwell TS, Christman $\mathrm{JW}$, Brigham KL: Dysregulated cytokine production in human cystic fibrosis bronchial epithelial cells. Inflammation 2001, 25:145-55.

6. Smith RS, Smith TJ, Blieden TM, Phipps RP: Fibroblasts as sentinel cells. Synthesis of chemokines and regulation of inflammation. Am J Pathol 1997, 151:317-22.

7. Wedzicha JA, Seemungal TA, MacCallum PK, Paul EA, Donaldson GC, Bhowmik A, Jeffries DJ, Meade TW: Acute exacerbations of chronic obstructive pulmonary disease are accompanied by elevations of plasma fibrinogen and serum IL-6 levels. Thromb Haemost 2000, 84:210-5

8. Breen EC, Rezai AR, Nakajima K, Beall GN, Mitsuyasu RT, Hirano T, Kishimoto T, Martinez-Maza O: Infection with HIV is associated with elevated IL-6 levels and production. J Immunol 1990, 144:480-4

9. Ott M, Lovett JL, Mueller L, Verdin E: Superinduction of IL-8 in T cells by HIV-1 Tat protein is mediated through NF-kappaB factors. J Immunol 1998, 160:2872-80.

10. Okamoto S, Mukaida N, Yasumoto K, Rice N, Ishikawa Y, Horiguchi H, Murakami S, Matsushima K: The interleukin-8 AP-1 and kappa B-like sites are genetic end targets of FK506-sensitive pathway accompanied by calcium mobilization. J Biol Chem 1994, 269:8582-9.

11. Yasumoto K, Okamoto S, Mukaida N, Murakami S, Mai M, Matsushima K: Tumor necrosis factor alpha and interferon gamma synergistically induce interleukin 8 production in a human gastric cancer cell line through acting concurrently on AP-1 and NF-kB-like binding sites of the interleukin 8 gene. J Biol Chem 1992, 267:22506-11.

12. Harris SG, Smith RS, Phipps RP: 15-deoxy-Delta 12,14-PGJ2 induces IL-8 production in human $T$ cells by a mitogen-activated protein kinase pathway. J Immunol 2002, 168:1372-9.

13. Ishihara K, Hirano T: IL-6 in autoimmune disease and chronic inflammatory proliferative disease. Cytokine Growth Factor Rev 2002, 13:357-68.

14. Ginn-Pease ME, Whisler RL: Optimal NF kappa B mediated transcriptional responses in Jurkat $T$ cells exposed to oxidative stress are dependent on intracellular glutathione and costimulatory signals. Biochem Biophys Res Commun 1996, 226:695-702.

15. Aifantis I, Gounari F, Scorrano L, Borowski C, von Boehmer H: Constitutive pre-TCR signaling promotes differentiation through $\mathrm{Ca} 2+$ mobilization and activation of NF-kappaB and NFAT. Nat Immuno/ 2001, 2:403-9.

16. Bassuk AG, Leiden JM: A direct physical association between ETS and AP-1 transcription factors in normal human T cells. Immunity 1995, 3:223-37.

17. Chang JH, Pratt JC, Sawasdikosol S, Kapeller R, Burakoff SJ: The small GTPbinding protein Rho potentiates AP-1 transcription in T cells. Mol Cell Biol 1998, 18:4986-93.

18. Boise LH, Petryniak B, Mao X, June CH, Wang CY, Lindsten T, Bravo R, Kovary K, Leiden JM, Thompson CB: The NFAT-1 DNA binding complex in activated T cells contains Fra-1 and JunB. Mol Cell Biol 1993, 13:1911-9.

19. Rooney JW, Hoey $\mathrm{T}$, Glimcher $\mathrm{LH}$ : Coordinate and cooperative roles for NF-AT and AP-1 in the regulation of the murine IL-4 gene. Immunity 1995, 2:473-83.

20. Tsai EY, Jain J, Pesavento PA, Rao A, Goldfeld AE: Tumor necrosis factor alpha gene regulation in activated T cells involves ATF-2/Jun and NFATp. Mol Cell Biol 1996, 16:459-67.

21. Vacca A, Felli MP, Farina AR, Martinotti S, Maroder M, Screpanti I, Meco D, Petrangeli E, Frati L, Gulino A: Glucocorticoid receptor-mediated suppression of the interleukin 2 gene expression through impairment of the cooperativity between nuclear factor of activated T cells and AP1 enhancer elements. J Exp Med 1992, 175:637-46.

22. Yang Y, Pares-Matos El, Tesmer VM, Dai C, Ashworth S, Huai J, Bina M: Organization of the promoter region of the human NF-IL6 gene. Biochim Biophys Acta 2002, 1577:102-8.

23. Standiford TJ, Kunkel SL, Strieter RM: Interleukin-8: a major mediator of acute pulmonary inflammation. Reg Immunol 1993, 5:134-41.

24. Heinrich PC, Behrmann I, Haan S, Hermanns HM, Muller-Newen G, Schaper F: Principles of interleukin (IL)-6-type cytokine signalling and its regulation. Biochem $\mathrm{J}$ 2003, 374:1-20.

25. Tilg H, Trehu E, Atkins MB, Dinarello CA, Mier JW: Interleukin-6 (IL-6) as an anti-inflammatory cytokine: induction of circulating IL-1 receptor antagonist and soluble tumor necrosis factor receptor p55. Blood 1994, 83:113-8

26. Heasley LE, Han SY: JNK regulation of oncogenesis. Mol Cells 2006 21:167-73.

27. Narayan P, Holt B, Tosti R, Kane LP: CARMA1 is required for Akt-mediated NF-kappaB activation in T cells. Mol Cell Biol 2006, 26:2327-36.

28. Kanno T, Siebenlist U: Activation of nuclear factor-kappaB via T cell receptor requires a Raf kinase and $\mathrm{Ca} 2+$ influx. Functional synergy between Raf and calcineurin. J Immunol 1996, 157:5277-83.

29. Lorentz A, Klopp I, Gebhardt T, Manns MP, Bischoff SC: Role of activator protein 1, nuclear factor-kappaB, and nuclear factor of activated T cells in $\mathrm{lg} \mathrm{E}$ receptor-mediated cytokine expression in mature human mast cells. J Allergy Clin Immuno/ 2003, 111:1062-8.

30. Ruland J, Mak TW: Transducing signals from antigen receptors to nuclear factor kappaB. Immunol Rev 2003, 193:93-100.

31. Franklin RA, Tordai A, Patel H, Gardner AM, Johnson GL, Gelfand EW: Ligation of the T cell receptor complex results in activation of the Ras/ Raf-1/MEK/MAPK cascade in human T lymphocytes. J Clin Invest 1994 93:2134-40

32. Holmstrom TH, Schmitz I, Soderstrom TS, Poukkula M, Johnson VL, Chow SC, Krammer PH, Eriksson JE: MAPK/ERK signaling in activated T cells inhibits CD95/Fas-mediated apoptosis downstream of DISC assembly. Embo J 2000, 19:5418-28.

33. Lyakh L, Ghosh P, Rice NR: Expression of NFAT-family proteins in normal human T cells. Mol Cell Biol 1997, 17:2475-84.

34. Macian F, Lopez-Rodriguez C, Rao A: Partners in transcription: NFAT and AP-1. Oncogene 2001, 20:2476-89.

35. Kyriakis JM, Avruch J: Sounding the alarm: protein kinase cascades activated by stress and inflammation. J Biol Chem 1996, 271:24313-6.

36. Park KA, Byun HS, Won M, Yang KJ, Shin S, Piao L, Kim JM, Yoon WH, Junn E, Park J, et al:: Sustained activation of protein kinase $C$ downregulates nuclear factor-kappaB signaling by dissociation of IKK-gamma and Hsp90 complex in human colonic epithelial cells. Carcinogenesis 2007, 28:71-80.

37. Wang JE, Jorgensen PF, Almlof M, Thiemermann C, Foster SJ, Aasen AO, Solberg R: Peptidoglycan and lipoteichoic acid from Staphylococcus aureus induce tumor necrosis factor alpha, interleukin 6 (IL-6), and IL10 production in both $T$ cells and monocytes in a human whole blood model. Infect Immun 2000, 68:3965-70.

38. Antonsson A, Hughes K, Edin S, Grundstrom T: Regulation of c-Re nuclear localization by binding of Ca2+/calmodulin. Mol Cell Biol 2003 23:1418-27.

39. Opal SM, DePalo VA: Anti-inflammatory cytokines. Chest 2000 , 117:1162-72

40. Kane LP, Andres PG, Howland KC, Abbas AK, Weiss A: Akt provides the CD28 costimulatory signal for up-regulation of IL-2 and IFN-gamma but not TH2 cytokines. Nat Immunol 2001, 2:37-44.

41. Cheadle C, Fan J, Cho-Chung YS, Werner T, Ray J, Do L, Gorospe M, Becker KG: Control of gene expression during $T$ cell activation: alternate regulation of mRNA transcription and mRNA stability. BMC Genomics 2005, 6:75.

42. Roggia C, Gao Y, Cenci S, Weitzmann MN, Toraldo G, Isaia G, Pacifici R: Upregulation of TNF-producing T cells in the bone marrow: a key mechanism by which estrogen deficiency induces bone loss in vivo. Proc Natl Acad Sci USA 2001, 98:13960-5.

43. Dinarello CA: Proinflammatory and anti-inflammatory cytokines as mediators in the pathogenesis of septic shock. Chest 1997, 112:321S-329S

44. Groux H, Bigler M, de Vries JE, Roncarolo MG: Interleukin-10 induces a long-term antigen-specific anergic state in human CD4+ T cells. J Exp Med 1996, 184:19-29.

45. Jain J, Valge-Archer VE, Sinskey AJ, Rao A: The AP-1 site at $-150 \mathrm{bp}$, but not the NF-kappa B site, is likely to represent the major target of protein kinase $\mathrm{C}$ in the interleukin 2 promoter. J Exp Med 1992, 175:853-62

46. Brown K, Park S, Kanno T, Franzoso G, Siebenlist U: Mutual regulation of the transcriptional activator NF-kappa B and its inhibitor, I kappa Balpha. Proc Natl Acad Sci USA 1993, 90:2532-6.

47. Scharschmidt E, Wegener E, Heissmeyer V, Rao A, Krappmann D: Degradation of $\mathrm{Bcl} 10$ induced by T-cell activation negatively regulates NF-kappa B signaling. Mol Cell Biol 2004, 24:3860-73. 
48. Ebinu JO, Stang SL, Teixeira C, Bottorff DA, Hooton J, Blumberg PM, Barry M, Bleakley RC, Ostergaard HL, Stone JC: RasGRP links T-cell receptor signaling to Ras. Blood 2000, 95:3199-203.

49. Berry N, Nishizuka Y: Protein kinase $C$ and T cell activation. Eur J Biochem 1990, 189:205-14

50. Manicassamy S, Sadim M, Ye RD, Sun Z: Differential roles of PKC-theta in the regulation of intracellular calcium concentration in primary $T$ cells. J Mol Biol 2006, 355:347-59.

51. Barnes PJ, Adcock IM: NF-kappa B: a pivotal role in asthma and a new target for therapy. Trends Pharmacol Sci 1997, 18:46-50.

52. Makarov SS: NF-kappaB as a therapeutic target in chronic inflammation: recent advances. Mol Med Today 2000, 6:441-8.

53. Tergaonkar V: NFkappaB pathway: a good signaling paradigm and therapeutic target. Int J Biochem Cell Biol 2006, 38:1647-53.

54. Dolcet X, Llobet D, Pallares J, Matias-Guiu X: NF-kB in development and progression of human cancer. Virchows Arch 2005, 446:475-82.

doi: $10.1186 / 1471-2172-11-26$

Cite this article as: Khalaf et al., Differential cytokine regulation by NF-?B and AP-1 in Jurkat T-cells BMC Immunology 2010, 11:26

Submit your next manuscript to BioMed Central and take full advantage of:

- Convenient online submission

- Thorough peer review

- No space constraints or color figure charges

- Immediate publication on acceptance

- Inclusion in PubMed, CAS, Scopus and Google Scholar

- Research which is freely available for redistribution

Submit your manuscript at www.biomedcentral.com/submit
C Biomed Central 